\title{
The Purpose of This Study Was to Improve Students' Critical Thinking Skills in The Civics Muple in Graduate Sentences in Class 4
}

\section{Cahyo Kurmai Setiyawan}

\author{
SD Negeri 2 Besuki \\ cahyokurmaisetiyawan@gmail.com
}

\section{Article History \\ accepted 14/11/2020}

approved $21 / 11 / 2020$ published 26/11/2020

\begin{abstract}
The purpose of this study was to improve students' critical thinking skills in Civics muple class IV with the Think Pair Share Type Cooperative learning model. The research conducted was two cycles of Class Action Research (CAR), with each cycle consisting of one meeting. The stages of each cycle are planning, implementing, observing and reflecting. Each meeting is carried out a pre test and post test to determine the progress of students. In the first cycle students who completed after carrying out the post test were 58\%. In the second cycle students who completed after carrying out the post test were $75 \%$. These results indicate that the application of the Think Pair Share Type Cooperative model can improve student learning outcomes, especially Civics muple at SD Negeri 2 Besuki.
\end{abstract}

Keywords: Cooperative type think pair share, critical thinking, PKn

\section{Abstrak}

Tujuan dari penelitian ini adalah untuk meningkatkan kemampapuan berpikir kritis siswa pada mupel PKn di Sekolah Dasar kelas IV dengan model pembelajaran Kooperatif Tipe Think Pair Share. Penelitian yang dilakukan adalah Penelitian Tindakan Kelas (PTK) sebanyak dua siklus, dengan setiap siklusnya terdiri dari satu pertemuan. Tahapan setiap siklusnya adalah perencanaan, pelaksanaan, observasi dan refleksi. Setiap pertemuan dilakukan pre test dan post test untuk mengetahui perkembangan peserta didik. Pada siklus I peserta didik yang tuntas setelah melaksanakan post test sebesar $52,6 \%$. Pada siklus II peserta didik yang tuntas setelah melaksanakan post test sebesar $84,2 \%$. Hasil ini menunjukan bahwa penerapan model Kooperatif Tipe Think Pair Share dapat meningkatkan hasil belajar peserta didik khususnya mupel PKn di SD Negeri 2 Besuki.

Kata kunci: Kooperatif tipe think pair share, berpikir kritis, Pkn

Social, Humanities, and Education Studies (SHEs): Conference Series https://jurnal.uns.ac.id/shes

p-ISSN 2620-9284

e-ISSN 2620-9292 


\section{PENDAHULUAN}

Badan Standar Nasional Pendidikan (2006) mengemukakan bahwa tujuan pendidikan dasar adalah meletakkan dasar kecerdasan, pengetahuan, kepribadian, akhlak mulia, serta keterampilan untuk hidup mandiri dan mengikuti pendidikan lebih lanjut. Dalam hal ini berarti proses pendidikan berujung pada pembentukan sikap, pengembangan kecerdasan atau intelektual serta pengembangan keterampilan siswa sesuai kemampuan dan kebutuhan. Ketiga aspek ini (sikap, kecerdasan dan keterampilan) adalah arah dan tujuan pendidikan yang harus diupayakan.

Belajar adalah aktivitas mental/psikis yang berlangsung dalam interaksi aktif dengan lingkungan yang menghasilkan perubahan-perubahan dalam pengetahuan, keterampilan dan sikap. Tujuan pendidikan tersebut dapat tercapai apabila guru mampu mewujudkan suatu proses belajar mengajar yang baik. Guru harus mampu mengetahui karakteriktistik peserta didik dan juga materi yang akan disampaikan.

Kesulitan peserta didik pada muatan pelajaran PKn terletak pada penguasaan materi karena pembelajaran jarak jauh hanya menggunakan aplikasi Whatsapp. Dari hasil tersebut di atas, diperoleh rerata untuk tingkat berpikir kritis siswa adalah sebesar 70,9 dari jumlah keseluruhan nilai siswa satu kelas. Jumlah siswa yang mencapai keberhasilan sebanyak 7 siswa dari 19 siswa atau dalam jumlah persen yaitu sebesar $36,8 \%$, sedangkan sebanyak 12 siswa dari19 siswa atau dalam jumlah persen yaitu $63,2 \%$, belum mencapai kriteria keberhasilan karena masih tergolong dalam kriteria rendah.

Hasil belajar peserta didik yang kurang diakibatkan oleh kelemahan guru dan peserta didik. Kelemahan guru tersebut adalah kurangnya kemampuan untuk memanfaatkan teknologi dalam pembelajaran jarak jauh yang dapat menarik perhatian peserta didik, kurangnya kemampuan untuk menciptakan suasana kelas daring yang menarik dan kurangnya kemampuan untuk merangsang daya kritis siswa masih rendah. Sebaliknya kelemahan peserta didik adalah kesulitan menyampaikan dan memahami pembelajaran melalui pembelajaran daring.

\section{METODE}

Penelitian ini adalah penelitian tindakan kelas (Classroom Action Research) dengan menerapkan Media audiovisual. Menurut Kurt Lewin dalam Kunandar (2011: 42) penelitian tindakan kelas ini terdiri dari empat tahapan dasar yaitu perencanaan (planning), pelaksanaan (acting), pengamatan (observing) dan refleksi (reflecting). Analisis penelitian ini adalah analisis deskriptif kuantitafif kualitatif dimana dalam penelitian ini selain penyajian hasil berupa data maupun angka peneliti juga menentukan bagaimana cara pengolahan hasil penelitian yakni dengan membuat analisisnya dengan menerapkan model penelitian Cooperative Tipe Think Pair Share Penelitian ini dilaksanakan pada peserta didik kelas IV SD Negeri 2 Besuki Tahun Ajaran 2020/2021 selama dua siklus secara daring menggunakan aplikasi Zoom cloud meet dengan satu pertemuan disetiap siklusnya. Siklus I dilaksanakan pada tanggal 12 November 2020. Siklus II dilaksanakan pada tanggal 23 November 2020. Teknik pengumpulan data yang dilakukan dengan observasi dan tes, baik pre test maupun post test. Observasi meliputi observasi keterlaksanaan model pembelajaran Cooperative Tipe Think Pair Share, sikap peserta didik dan keterampilan. Untuk hasil belajar menggunakan tes melalui Google form.

\section{HASIL DAN PEMBAHASAN}

Pada siklus I pembelajaran dilaksanakan selama satu pertemuan, setiap pertemuan diadakan pre test dan post test. Untuk mengetahui perkembangan peserta didik selama pembelajaran. Siklus I membahas materi membuat kalimat ungkapan saran, dan penyelesaian masalah sederhana. Pembelajaran dengan model 
Cooperative Tipe Think Pair Share dilaksanakan dengan 6 langkah secara berurutan mulai dari Stimulation (Stimulasi/pemberian rangsangan), Problem statement (Pernyataan/Identifikasi masalah), Data Collection (Pengumpulan data), Data Proccessing (Pengolahan data), Verivication Data (Pembuktian), Generalization (Menarik kesimpulan). Berikut ini adalah hasil belajar peserta didik pada siklus I yang bisa dilihat pada tabel berikut.

Tabel 1. Hasil Peserta didik Siklus I

\begin{tabular}{ccccccccc}
\hline & \multicolumn{3}{c}{ Pre test } & \multicolumn{4}{c}{ Post test } \\
\cline { 2 - 9 } Siklus 1 & $\begin{array}{l}\text { Pesdik } \\
\text { tuntas }\end{array}$ & $\begin{array}{l}\text { Pesdik } \\
\text { belum } \\
\text { tuntas }\end{array}$ & $\begin{array}{l}\text { Pesdik } \\
\text { tuntas }\end{array}$ & $\begin{array}{l}\text { Pesdik } \\
\text { belum } \\
\text { tuntas }\end{array}$ \\
\cline { 2 - 10 } & $\mathrm{Jml}$ & $\%$ & $\mathrm{Jml}$ & $\%$ & $\mathrm{Jml}$ & $\%$ & $\mathrm{Jml}$ & $\%$ \\
\hline Pertemuan 1 & 7 & 36,8 & 12 & 63,2 & 10 & 52,6 & 9 & 47,4 \\
\hline
\end{tabular}

Dari hasil tersebut di atas, diperoleh rerata untuk tingkat berpikir kritis siswa adalah sebesar 70,9 dari jumlah keseluruhan nilai siswa satu kelas. Jumlah siswa yang mencapai keberhasilan sebanyak 7 siswa dari 19 siswa atau dalam jumlah persen yaitu sebesar $36,8 \%$, sedangkan sebanyak 12 siswa dari19 siswa atau dalam jumlah persen yaitu $63,2 \%$, belum mencapai kriteria keberhasilan karena masih tergolong dalam kriteria rendahdapat diketahui perolehan skor rerata pada siklus I yaitu sebesar 75,5 dari keseluruhan jumlah nilai siswa satu kelas. Jumlah siswa yang telah mencapai kriteria keberhasilan sebanyak 10 siswa dari 19 siswa, yang dalam jumlah persen yaitu $52,6 \%$, sedangkan sebanyak 9 siswa dari 19 siswa dan dalam jumlah persen yaitu $47,4 \%$ masih belum mencapai kriteria keberhasilan yang ditentukan. Berikut ini adalah hasil belajar peserta didik pada siklus II yang bisa dilihat pada tabel berikut.

Tabel 1. Hasil Peserta didik Siklus II

\begin{tabular}{ccccccccc} 
& \multicolumn{4}{c}{ Pre test } & & \multicolumn{3}{c}{ Post test } \\
\cline { 2 - 9 } Siklus 1 & $\begin{array}{c}\text { Pesdik } \\
\text { tuntas }\end{array}$ & $\begin{array}{c}\text { Pesdik } \\
\text { belum } \\
\text { tuntas }\end{array}$ & $\begin{array}{c}\text { Pesdik } \\
\text { tuntas }\end{array}$ & $\begin{array}{l}\text { Pesdik } \\
\text { belum } \\
\text { tuntas }\end{array}$ \\
\cline { 2 - 9 } & Jml & $\%$ & Jml & $\%$ & Jml & $\%$ & Jml & $\%$ \\
\hline $\begin{array}{c}\text { Pertemuan } \\
1\end{array}$ & 10 & 52,6 & 9 & 47,4 & 16 & 84,2 & 3 & 15,8 \\
\hline
\end{tabular}

Berdasarkan tabel di atas, dapat diketahui pada siklus II diperoleh skor rerata sebesar 80,5 dari seluruh jumlah nilai siswa satu kelas. Siswa yang telah mencapai kriteria keberhasilan sebanyak 16 siswa dari 19 siswa, yang jika ditulis dalam persen yaitu berjumlah $84,2 \%$. Walaupun ada 3 siswa dari 19 siswa, dan jika ditulis dalam persen yaitu $15,8 \%$ masih belum mencapai kriteria keberhasilan yang ditentukan Setelah melakukan refleksi pada siklus II, maka diputuskan untuk melanjutkan pada siklus III. Hal ini dilakukan agar mengetahui sejauh mana penerapan tink pair and sher untuk meningkatkan hasil belajar peserta didik tidak hanya meningkatkan tetapi juga mempertahankan hasil belajar peserta didik. Dari dua siklus yang sudah dilaksanakan selama 2 pertemuan dapat dipastikan bahwa model pembelajaran tink pair and sher adapat meningkatkan Berpikir Kritis siswa peserta didik pada mupel PKn Kelas IV di SD Negeri 2 Besuki. 


\section{SIMPULAN}

Penerapan pembelajaran tink pair and sher dapat meningkatkan hasil belajar PKn pada ketrampilan Berpikir kritis siswa kelas IV SD Negeri 2 Besuki. Peningkatan yang terjadi karena adanya kesan pembelajaran yang mendalam dari peserta didik tehadap materi yang diajarkan melalui setiap sintak yang dilalui. Peserta didik akan selalu teringat akan materi yang diajarkan dikarenakan mereka menyampaikan . Berdasarkan penelitian yang telah dilaksanakan salah satu model pembelajaran yang harus dikuasai guru adalah Thing Pair and Sher karena model ini sangat cocok digunakan dalam keadaan pandemi seperti ini, apalagi dalam kondisi belajar dari rumah.

\section{DAFTAR PUSTAKA}

Agus Suprijono. (2013). Cooperatif Learning. Yogyakarta: Bima Bayu Atijah. Anita Lie. (2010). Cooperative Learning. Jakarta: PT. Grasindo.

Asrori, dkk. (2009). Penelitian Tindakan Kelas (peningkatan Kompetensi Profesional Guru. Yogyakarta: Multi Pressindo.

Badan Standar Nasional Pendidikan. (2006). Standar Isi. Jakarta.

Chaedar Alwasilah. (2009). Contextual Teaching \& Learning. Bandung: MLC Departemen Pendidikan Nasional. (2006). Kurikulum Tingkat Satuan Pendidikan.

Jakarta: Dharma Bhakti.

Eti Nurhayati. (2011). Psikologi Pendidikan Inovatif. Yogyakarta: Pustaka Pelajar. 